\title{
Viral and Immunological Analytes are Poor Predictors of the Clinical Treatment Response in Kaposi's Sarcoma Patients
}

Salum J. Lidenge ${ }^{1,2,3,4}$, For Yue Tso ${ }^{1,2}$, Yasaman Mortazavi ${ }^{1,2}$, John R. Ngowi ${ }^{3}$, Danielle M. Shea ${ }^{1}$, Julius Mwaiselage ${ }^{3,4}$, Charles Wood ${ }^{1,2,5, * \mathbb{C}}$ and John T. West ${ }^{1,5, *}$

1 Nebraska Center for Virology, Lincoln, NE 68583, USA; sjlidenge@yahoo.co.uk (S.J.L.); ftso2@unl.edu (F.Y.T.); yass.mortazavi@yahoo.com (Y.M.); danielle.shea@unl.edu (D.M.S.)

2 School of Biological Sciences, University of Nebraska-Lincoln, Lincoln, NE 68588, USA

3 Department of Academics and Research, Ocean Road Cancer Institute, P. O. Box 3592 Dar es Salaam, Tanzania; jrngowi146@gmail.com (J.R.N.); jmwaiselage@yahoo.com (J.M.)

4 Department of Clinical Oncology, Muhimbili University of Health and Allied Sciences, P. O. Box 65001 Dar es Salaam, Tanzania

5 Department of Biochemistry, University of Nebraska-Lincoln, Lincoln, NE 68588, USA

* Correspondence: cwood1@unl.edu (C.W.); jwest2@unl.edu (J.T.W.); Tel.: +1-402-202-472-4550 (C.W.); +1-402-202-472-4550 (J.T.W.)

Received: 17 May 2020; Accepted: 12 June 2020; Published: 16 June 2020

\begin{abstract}
Kaposi's sarcoma-associated herpes virus (KSHV) is the etiologic agent for Kaposi's sarcoma (KS). The prognostic utility of KSHV and HIV-1 (human immunodeficiency virus) viremia as well as immunological parameters in clinical management of participants with KS is unclear. The objective of this study was to investigate viral and immunological parameters as predictors of KS treatment responses in participants with KS from sub-Saharan Africa (SSA). Plasma KSHV-DNA, HIV-1 viral load, total anti-KSHV antibody, KSHV-neutralizing antibody (nAb), cytokine/chemokine levels, and T-cell differentiation subsets were quantified before and after KS treatment in 13 participants with $\mathrm{KS}$ and in $13 \mathrm{KSHV}$-infected asymptomatic control individuals. One-way analysis of variance and the Mann-Whitney t-test were used to assess differences between groups where $p$-values $<0.05$ were considered significant. Subjects with patch and plaque KS lesions responded more favorably to treatment than those with nodular lesions. Pre-treatment and post-treatment levels of plasma KSHV-DNA, HIV-1 viral load, KSHV-Ab responses, cytokines, and T-cell populations did not predict the KS treatment response. Elevated KSHV-humoral and cytokine responses persisted in participants with KS despite a clinical KS response. While patch and plaque KS lesions were more common among treatment responders, none of the analyzed viral and immunological parameters distinguished responders from non-responders at baseline or after treatment.
\end{abstract}

Keywords: Kaposi's sarcoma; immune responses; neutralizing antibody; cytokine; T-cells; treatment response; HIV-1; KSHV; sub-Saharan Africa

\section{Introduction}

Kaposi's sarcoma (KS), which is a multifocal angio-proliferative sarcoma commonly found on skin and mucosal surfaces, is caused by the Kaposi's sarcoma-associated herpes virus (KSHV) or human herpes virus-8 (HHV-8) [1]. KSHV infection is endemic in sub-Saharan Africa (SSA) with prevalence as high as $90 \%$ in some countries [2-4]. Before the AIDS epidemic, HIV negative African-endemic KS (EnKS) comprised $4-10 \%$ of African adult cancers [5,6]. With the ongoing HIV/AIDS epidemic, 
AIDS-associated/epidemic KS (EpKS) has become the most common cancer in HIV-1 infected African individuals $[7,8]$.

In developed countries, anti-retroviral therapy (ART) has led to significant decline in KS incidence in HIV-1 infected individuals, even though recent reports demonstrate that KS still occurs in individuals with reconstituted $\mathrm{CD} 4^{+}$T-cell counts and a suppressed HIV-1 plasma viral load [9-13]. A similar decline in KS incidence has not been observed in SSA where KS remains one of the top five cancers despite of increased ART coverage, uptake, and adherence $[9,14,15]$. Lack of early disease recognition, advanced presentation, and lack of effective treatments all contribute to high KS morbidity and mortality [16-18].

KS treatment in SSA consists of conventional chemotherapy and/or radiotherapy [19-22]. The readily available KS treatments are suboptimal with no curative effects $[17,21,23]$. First-line KS treatments employed in developed countries, such as liposomal doxorubicin, alone or in combination with other drugs, are not readily accessible [24]. With currently available KS treatments, approximately $50 \%$ of African participants with KS achieve some degree of remission $[17,21]$. Unfortunately, approximately $50 \%$ of initially remitting patients experience recurrence within 6 months post-treatment [21]. Factors that correlate with KS treatment responses are not currently understood. Since KS is associated with immune suppression, as shown by the high incidence of KS in HIV-1 co-infected individuals, it is possible that immunological differentials before and after KS treatment would associate with response to treatment. Identification of pre-treatment factors associated with a response might provide prognostic insight whereas differentials in markers post-treatment might suggest mechanisms associated with KS control. Therefore, investigation of participants with KS before and after treatment could be crucial for developing more effective management strategies for KS.

Our recent analysis of immunological responses in participants with EpKS and EnKS prior to initiation of treatment revealed differentials and potential dysregulation in antibody and cytokine responses in both participants with EpKS and EnKS [25]. Cytokines associated with increased antibody production (IL-6, IL-5, and IL-10) as opposed to inflammation and cellular responses [26-29] were significantly elevated in participants with KS at baseline. Since KS treatment with chemotherapy or radiotherapy can result in remission, we hypothesized that changes in viral and immunological parameters before and after treatment would differentiate responders from non-responders. Such changes could be applied to better stratify patients and improve KS management. However, our study reveals immune dysregulation persists in treated participants with KS independently of the therapeutic outcome.

\section{Results}

\subsection{Characteristics of the Study Subjects}

To investigate viral and immunological profiles as predictors of the KS treatment response, a total of 26 individuals (eight KS responders and five non-responders with complete clinical information and $13 \mathrm{KSHV}$-infected asymptomatic controls, six HIV-1 ${ }^{-}$and seven $\mathrm{HIV}-1^{+}$) were recruited. The two control groups were comparable in age, gender, CD4 count, and KSHV status (Table 1). Similarly, there was no statistically significant difference between responders and non-responders in age, gender, KS lesion morphotype, duration of KS, or ART use and CD4 count at baseline. While the comparison of CD4 count did not reveal significant differences between groups of controls and participants with KS, KS non-responders had significantly lower CD4 count when compared to normal controls $\left(\mathrm{HIV}_{-} \mathrm{1}^{-}\right)(p=0.03)$. Participants with KS and controls had comparable duration to ART. Plasma HIV-1 viremia was also comparable between HIV-1 ${ }^{+}$controls and participants with KS despite detectable HIV-1 in a few of the participants with KS (Table 2). The major KS treatment modality was Adriamycin/Bleomycin/Vinblastine (ABV) chemotherapy except for two cases where radiotherapy alone was applied to patch and plaque KS lesions on the extremities (Table 1). 
Table 1. Characteristics of the study cohort at baseline.

\begin{tabular}{|c|c|c|c|c|c|}
\hline \multirow{2}{*}{ Variables } & \multicolumn{2}{|c|}{$\begin{array}{l}\text { Kaposi's Sarcoma-Associated } \\
\text { Herpes Virus (KSHV) Infected } \\
\text { Asymptomatic Controls }\end{array}$} & \multicolumn{2}{|c|}{$\begin{array}{c}\text { Participants with Kaposi's } \\
\text { Sarcoma (KS) }\end{array}$} & \multirow[t]{2}{*}{$p$-Values * } \\
\hline & HIV-1- $(n=6)$ & $\mathrm{HIV}^{+} \mathbf{1}^{+}(n=7)$ & $\begin{array}{c}\text { KS } \\
\text { Responders } \\
(n=8)\end{array}$ & $\begin{array}{c}\text { KS } \\
\text { Non-Responders } \\
(n=5)\end{array}$ & \\
\hline $\begin{array}{l}\text { Median age-years } \\
\text { (Range) }\end{array}$ & $49(33-55)$ & $36(34-48)$ & $38(26-57)$ & $44(39-58)$ & 0.05 \\
\hline Male gender (\%) & $4(67)$ & $3(43)$ & $4(50)$ & $5(100)$ & 0.07 \\
\hline Nodular KS lesions (\%) & NA & NA & $3(37.5)$ & $4(80)$ & 0.15 \\
\hline KS duration ** (Range) & NA & NA & $12(1-96)$ & $6(3-36)$ & 0.68 \\
\hline $\begin{array}{l}\text { Median CD4 count } \\
\text { (Range) }\end{array}$ & $620(303-1398)$ & $316(124-675)$ & $\begin{array}{c}377.5 \\
(130-887)\end{array}$ & $150(91-150)^{\wedge}$ & 0.09 \\
\hline $\begin{array}{l}\text { Plasma HIV-1 load } \\
\text { (copies/mL) }\end{array}$ & NA & BDL & $\begin{array}{c}3.5 \times 10^{4} \\
(\mathrm{BDL}-1.5 \mathrm{E} 5)\end{array}$ & $\begin{array}{c}1.0 \times 10^{4} \\
(\mathrm{BDL}-1.5 \mathrm{E} 4)\end{array}$ & 0.80 \\
\hline $\begin{array}{l}\text { Anti-retroviral therapy } \\
\text { (ART) duration *** } \\
\text { (Range) }\end{array}$ & NA & $12(1-36)$ & $8(1-36)$ & $24(0.25-72)$ & 0.52 \\
\hline
\end{tabular}

${ }^{*}$ Comparison between KS responders and non-responders. ${ }^{* *}$ Self-reported KS duration in months. ${ }^{* * *}$ ART duration in months. Applies for six KS responders only. Two KS responders were HIV negative KS patients. ^ Comparison between KSHV infected asymptomatic controls $\left(\mathrm{HIV}^{-}-^{-}\right)$and KS non-responders; $p=0.03$. By One-way ANOVA and Tukey correction. KS-Kaposi's sarcoma, ART-Antiretroviral Therapy, HIV-1-Human Immunodeficiency Virus type 1, NA-Not Applicable, BDL-Below detection limit, $n$-Group sample size, HIV-1-HIV-1 negative, HIV-1 ${ }^{+}$HIV-1 positive.

Table 2. Plasma Kaposi's sarcoma-associated herpes virus (KSHV) and human immunodeficiency virus (HIV)-1 detection by PCR.

\begin{tabular}{|c|c|c|c|c|c|c|c|c|}
\hline \multirow[t]{2}{*}{ ID } & \multicolumn{4}{|c|}{ KSHV Virion in Plasma (PCR) (Copies/mL) } & \multicolumn{2}{|c|}{ CD4 Count (Cells $/ \mu \mathrm{L})$} & \multicolumn{2}{|c|}{$\begin{array}{l}\text { HIV-1 Plasma Viral } \\
\text { Copies/mL }\end{array}$} \\
\hline & $\begin{array}{c}\text { Before } \\
\text { Treatment }\end{array}$ & $\begin{array}{c}\text { After } \\
\text { Treatment }\end{array}$ & $\begin{array}{c}\text { Before } \\
\text { Treatment }\end{array}$ & $\begin{array}{c}\text { After } \\
\text { Treatment }\end{array}$ & $\begin{array}{c}\text { Before } \\
\text { Treatment }\end{array}$ & $\begin{array}{c}\text { After } \\
\text { Treatment }\end{array}$ & $\begin{array}{c}\text { Before } \\
\text { Treatment }\end{array}$ & $\begin{array}{c}\text { After } \\
\text { Treatment }\end{array}$ \\
\hline 21147 & - & - & NA & NA & 887 & 523 & NA & NA \\
\hline 21182 & + & - & 1300 & NA & 854 & 1154 & NA & NA \\
\hline 21117 & + & - & BDL & NA & 130 & 262 & 3450 & BDL \\
\hline 21161 & - & - & NA & NA & 710 & 306 & 148,000 & 369,000 \\
\hline 21186 & + & + & 2100 & BDL & 143 & 211 & 34,700 & BDL \\
\hline 21220 & - & - & NA & NA & 167 & NR & BDL & BDL \\
\hline 21228 & - & - & NA & NA & 333 & 353 & BDL & BDL \\
\hline 21119 & + & - & BDL & NA & 221 & 244 & BDL & BDL \\
\hline
\end{tabular}

+ Positive, - Negative, KSHV—Kaposi's sarcoma herpes virus, NA-Not applicable, BDL-Below detection limit, HIV-1-Human immunodeficiency virus type 1, Grey shaded—Non-responders, No grey shade — Responders, NR-Not recorded.

\subsection{Similar Viral Profiles in Responders and Non-Responders of KS Treatment}

Although KSHV is mostly a cell associated virus, our previous analysis of KSHV detection in a peripheral blood mononuclear cell (PBMC) revealed a variable detection pattern and lacked association with anti-KSHV antibody responses [25]. Due to high anti-KSHV antibody responses in KS patients, we investigated KSHV viremia and antibody responses as predictors of the KS treatment response. DNase-I treated plasma was used to quantify KSHV virion DNA before and after treatment. Only three treatment responders and three non-responders had detectable KSHV viremia at baseline, and, when 
detectable, the baseline quantity of KSHV virions in plasma was comparable between responders and non-responders. However, after KS treatment, only one of six individuals (17\%) maintained detectable KSHV plasma viremia. The rest became undetectable (Table 2). KSHV viremia was below the detection limit for most of the plasma samples. Importantly, KSHV viremia after treatment did not correlate with the therapeutic response.

For the participants with EpKS and $\mathrm{HIV}-1^{+}$asymptomatic controls, the HIV-1 plasma viral load was largely undetectable before and after KS treatment, and CD4 ${ }^{+}$T-cell counts in the HIV- $1^{+}$subjects were similar to those in HIV-1- ${ }^{-}$controls (Table 1). Individuals with detectable plasma HIV-1 were either on ART for less than a month (2-individuals) or were experiencing ART failure (1-individual). With continued ART use, all patients attained HIV-1 viral suppression except one (21161) who was switched to the second line ART (Table 2). However, there were no statistically significant differences in pre-treatment or post-treatment CD4 count or HIV-1 plasma viral load between responders and non-responders or between controls and participants with KS. Importantly, none of the variables in Tables 1 and 2 are significantly associated with the KS treatment response by logistic regression analysis.

\subsection{Humoral Response Differentials between KS Treatment Responders and Non-Responders}

We previously reported high levels of total anti-KSHV Ab and KSHV-nAb in participants with KS prior to cancer therapy [25]. In this case, we tested whether titers of these Ab responses at baseline, or their changes in response to therapy, correlated with the outcome. Neither high nor low Ab titer at baseline was associated with the treatment response. However, non-responders had higher anti-KSHV $\mathrm{Ab}$ levels after treatment, which may be indicative of continuing low levels of viral expression without resulting in detectable plasma viremia ( $p=0.01$, Figure $1 \mathrm{~A})$. High anti-KSHV Ab titers have also been shown to correlate with KS disease [25,30]. The median KSHV-nAb titers and high or low KSHV-nAb titers before or after treatment also did not correlate with the response outcome (Figure 1B). Overall, despite undetectable KSHV plasma viremia, KSHV-specific humoral responses are still high after treatment but failed to differentiate responders from non-responders.
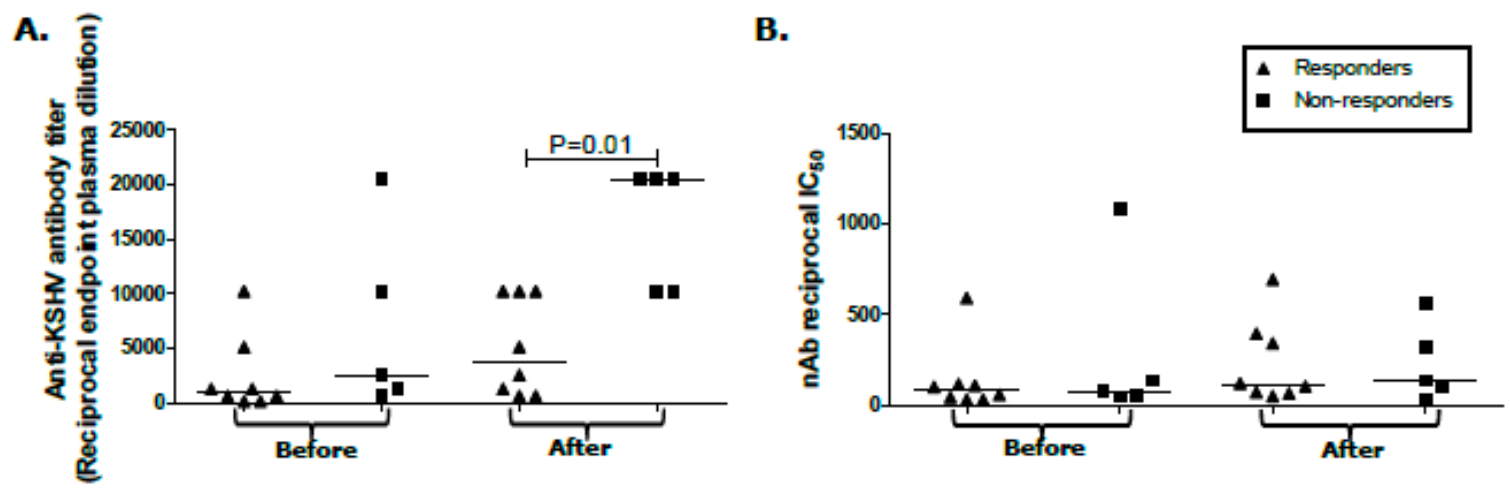

Figure 1. KSHV-specific humoral responses before and after treatment. (A) Immunofluorescence assay for total anti-KSHV antibody titers in plasma of participants with KS showing responders and non-responders before and after KS treatment (reciprocal endpoint plasma dilution). (B) KSHV-neutralizing antibody $(\mathrm{nAb})$ titer in plasma of participants with KS showing responders and non-responders before and after $\mathrm{KS}$ treatment, presented as a reciprocal of $50 \%$ inhibitory concentration $\left(\mathrm{IC}_{50}\right)$. Plasma samples that were nAb-positive at 1:50 dilution were re-assayed in two-fold dilutions of plasma from 1:50 to 1:800 to define the $\mathrm{IC}_{50}$. KSHV-seropositive samples with less than 50\% KSHV neutralization at 1:50 dilution were assigned a value of 30 in reciprocal $\mathrm{IC}_{50}$ plots.

\subsection{Cytokine/Chemokine Levels in Responders and Non-Responders Unaffected by KS Treatment}

We recently reported IL-5, IL-10, IL-6, CxCL-10, and TGF- $\beta$ elevation in both participants with EpKS and EnKS when compared to KSHV-infected asymptomatic controls prior to cancer therapy [25]. In this case, we tested whether baseline cytokine levels (high or low), or temporal changes in cytokine 
levels over KS treatment, predicted the KS treatment response. The average levels, the high or low levels of regulatory/inhibitory cytokines, IL-10 and TGF- $\beta$, and the anti-inflammatory cytokine, IL-5, did not vary significantly between responders and non-responders (Figure 2A-C). Similarly, the average levels of IL-6 and CxCL-10 did not correlate with the treatment response (Figure 2A,B). High versus low partitions of IL-6 and CxCL-10, before or after treatment, also did not correlate with the treatment response (Figure 2A,B). Overall, the elevation of inhibitory and regulatory cytokines in participants with KS after treatment compared to non-disease controls implicates persistent immune dysregulation.

A.

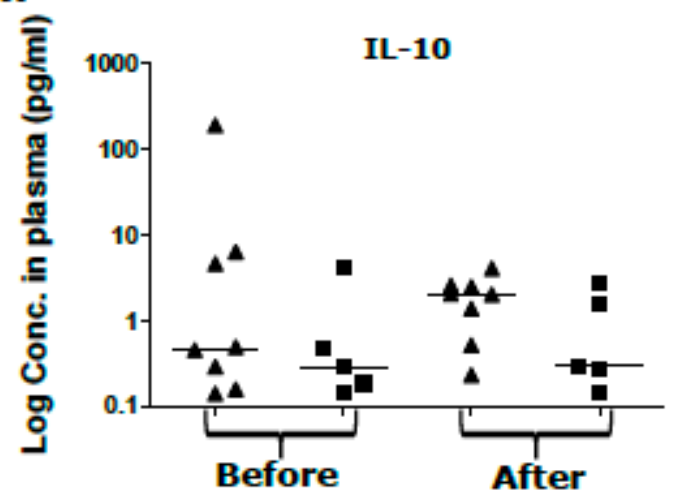

B.

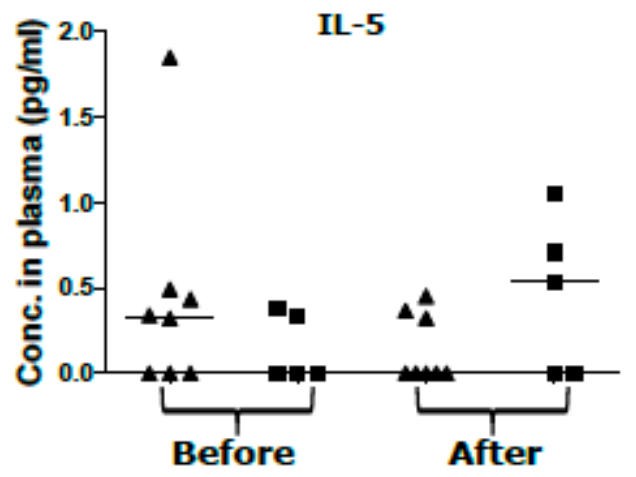

C.

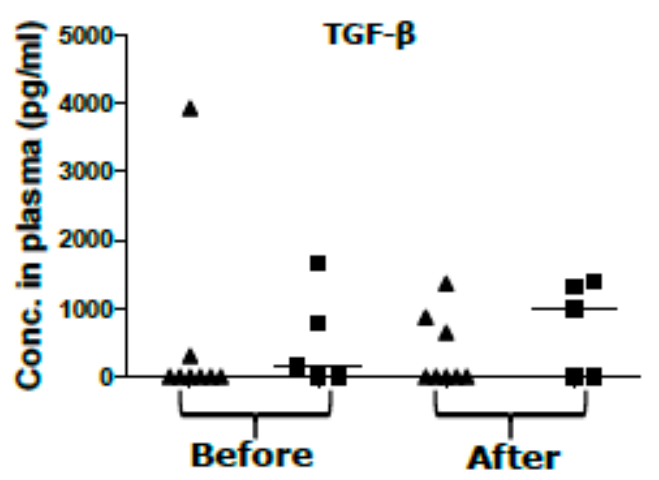

4 Responders

- Non-responders
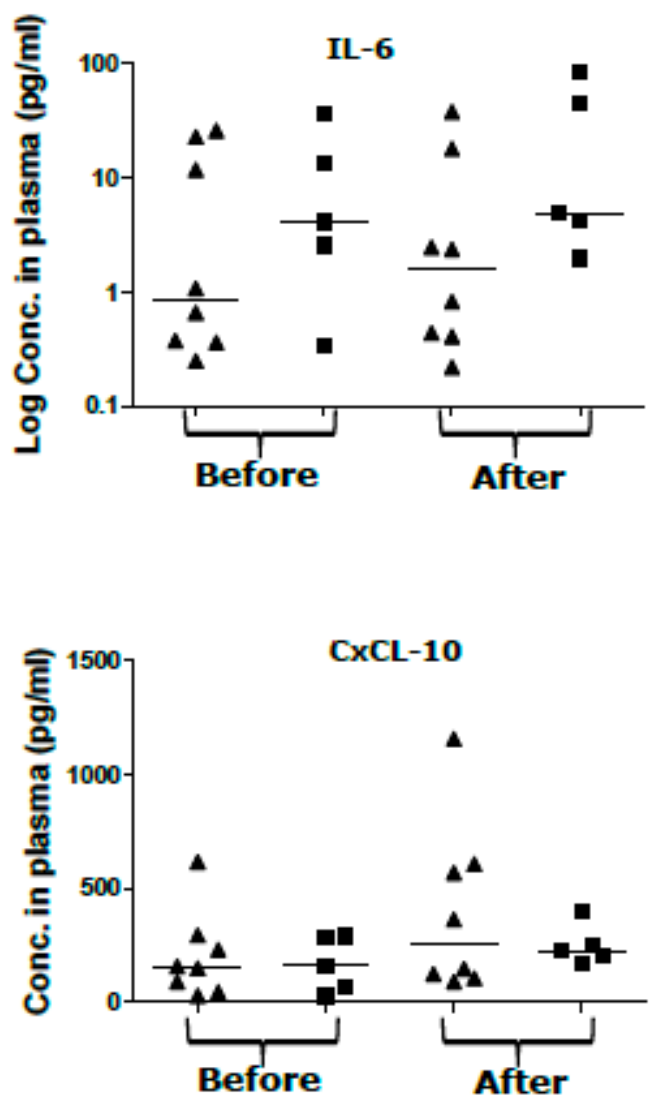

Figure 2. Cytokine/chemokine responses in plasma of participants with Kaposi's sarcoma (KS) showing responders and non-responders before and after KS treatment. (A) Interleukin-10 (IL-10), interleukin-6 (IL-6), (B) interleukin-5 (IL-5), chemokine CXCL10, and (C) transforming growth factor- $\beta$ (TGF- $\beta$ ). 


\subsection{T-Cell Populations Are Not Differential between KS Treatment Responders and Non-Responders}

As a result of antigenic stimulation, T-cells undergo phenotypic changes such as activation, differentiation, and proliferation [31,32]. We immuno-phenotyped peripheral blood T-cell populations from participants with KS before and after treatment to investigate whether T-cell subsets were associated with the KS treatment response. Naïve $\left[\mathrm{CD} 197^{+} / \mathrm{CD} 4 \mathrm{RO}^{-}\left(\mathrm{T}_{\mathrm{N}}\right)\right]$, effector $\left[\mathrm{CD} 197^{-} / \mathrm{CD} 45 \mathrm{RO}^{-}\right.$ $\left.\left(\mathrm{T}_{\mathrm{E}}\right)\right]$, effector memory $\left[\mathrm{CD} 197^{-} / \mathrm{CD} 4 \mathrm{RO}^{+}\left(\mathrm{T}_{\mathrm{EM}}\right)\right]$, central memory $\left[\mathrm{CD} 197^{+} / \mathrm{hCD} 4 \mathrm{RO}^{+}\left(\mathrm{T}_{\mathrm{CM}}\right) \mathrm{CD}^{+}\right.$, and $\mathrm{CD}^{+} \mathrm{T}$-cell populations were quantified by flow cytometry. Their activation $\left(\mathrm{CD} 38^{+} / \mathrm{Human}\right.$ Leucocyte Antigen/HLA-DR ${ }^{+}$), senescence $\left(\mathrm{CD} 57^{+} / \mathrm{CD} 28^{-} / \mathrm{hCD}^{-} 7^{-}\right)$, and proliferation $\left(\mathrm{Ki} 67^{+}\right)$profiles were also investigated. Compared to controls, there was an increase in proportions of $\mathrm{T}_{\mathrm{N}}(p=0.005)$ and a decrease of $\mathrm{T}_{\mathrm{EM}} \mathrm{CD} 8^{+} \mathrm{T}$-cells $(p=0.001)$ in $\mathrm{KS}$ responders (Figure 3A,C, respectively). In participants with $\mathrm{KS}, \mathrm{T}_{\mathrm{E}}$ and $\mathrm{T}_{\mathrm{CM}} \mathrm{CD} 8^{+} \mathrm{T}$-cells were comparable to controls (Figure 3B,D). No changes were noted in proportions of $\mathrm{CD}^{+} \mathrm{T}$-cell phenotypes over the course of treatment (Figure 3A-D). Similarly, none of the proportions of $\mathrm{CD}^{+} \mathrm{T}_{\mathrm{N}}, \mathrm{T}_{\mathrm{E}}, \mathrm{T}_{\mathrm{EM}}$, and $\mathrm{T}_{\mathrm{CM}}$ at baseline, or after treatment, correlated with the KS treatment response (Figure $3 \mathrm{~A}-\mathrm{D}$ ). Importantly, having high or low proportions $\mathrm{CD}^{+} \mathrm{T}_{\mathrm{N}}, \mathrm{T}_{\mathrm{E}}, \mathrm{T}_{\mathrm{EM}}$, and $\mathrm{T}_{\mathrm{CM}}$ before and after treatment also showed no significant correlation with the treatment response (Figure 3A-D).

^ Responders

- Non-responders
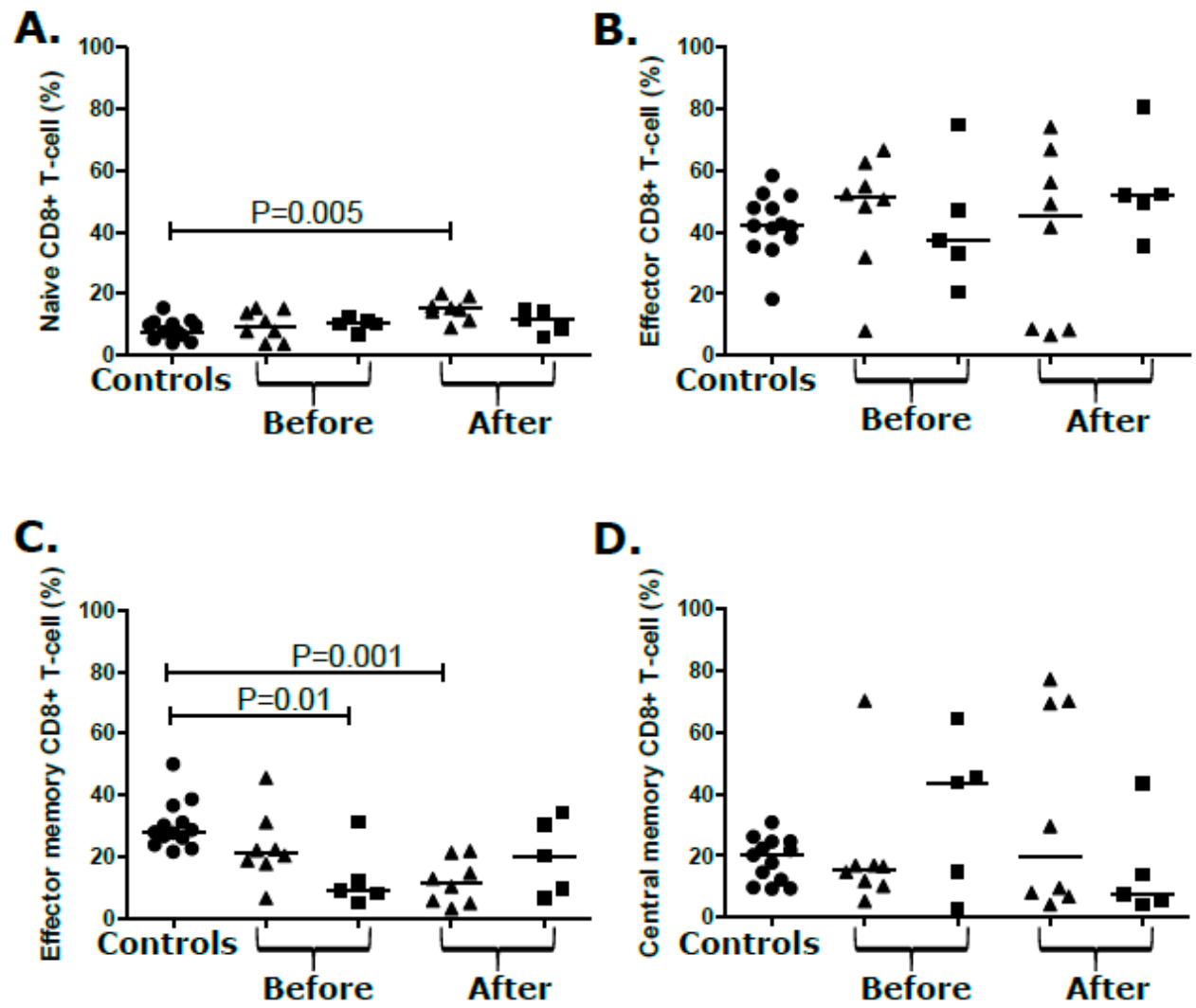

Figure 3. T-cell population $\left(\mathrm{CD}^{+}\right)$analysis from peripheral blood mononuclear cells (PBMCs). Percentage of $\mathrm{CD}^{+}$T-cell population expressing markers of $(\mathbf{A})$ naïve, (B) effector, $(\mathbf{C})$ effector memory, and (D) central memory $\mathrm{CD}^{+} \mathrm{T}$-cells in asymptomatic controls and responder and non-responders before and after treatment.

In the $\mathrm{CD}^{+}$compartment, proportions of $\mathrm{T}_{\mathrm{N}}, \mathrm{T}_{\mathrm{EM}}$, and $\mathrm{T}_{\mathrm{CM}}$ in participants with $\mathrm{KS}$ were comparable to controls (Figure $4 \mathrm{~A}, \mathrm{C}, \mathrm{D})$. However, there were decreased $\mathrm{CD} 4^{+} \mathrm{T}_{\mathrm{E}}(p=0.01)$ in 
KS responders when compared to the controls (Figure $4 \mathrm{~B}$ ), but this differential was maintained through treatment in comparison of the baseline to follow-up ( $p=0.04$, Figure $4 \mathrm{~B}$ ). There were no temporal/treatment-associated changes in the $\mathrm{CD}^{+}{ }^{+} \mathrm{T}$-cell phenotypes over the course of treatment (Figure $4 \mathrm{~A}-\mathrm{D})$. Similarly, none of the proportions of $\mathrm{CD}^{+} \mathrm{T}_{\mathrm{N}}, \mathrm{T}_{\mathrm{E}}, \mathrm{T}_{\mathrm{EM}}$, and $\mathrm{T}_{\mathrm{CM}}$ at baseline or after treatment correlated with the KS treatment response (Figure 4A-D). No significant changes were detected in activation, proliferation, and senescence markers in either the $\mathrm{CD} 8^{+}$or $\mathrm{CD} 4^{+} \mathrm{T}$-cell populations of responders and non-responders from pre-treatment or post-treatment time points (Figure 5 and Supplementary Figures S1 and S2). Overall, despite a demonstrated KS clinical treatment response, the proportions T-cell subsets before and after treatment were not correlative or predictive of the KS treatment response.

A Responders

- Non-responders

A.

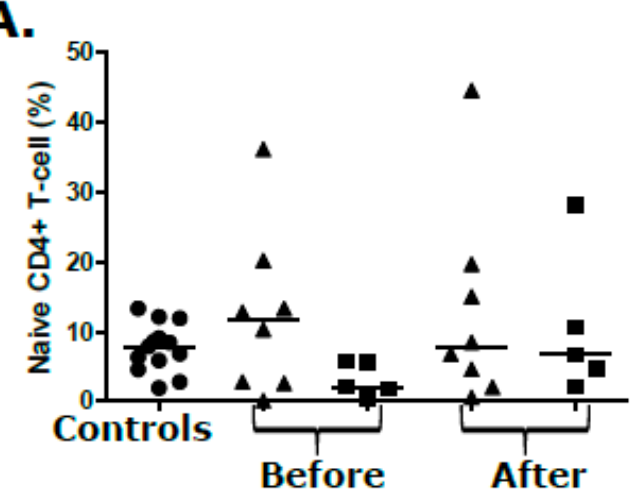

C.

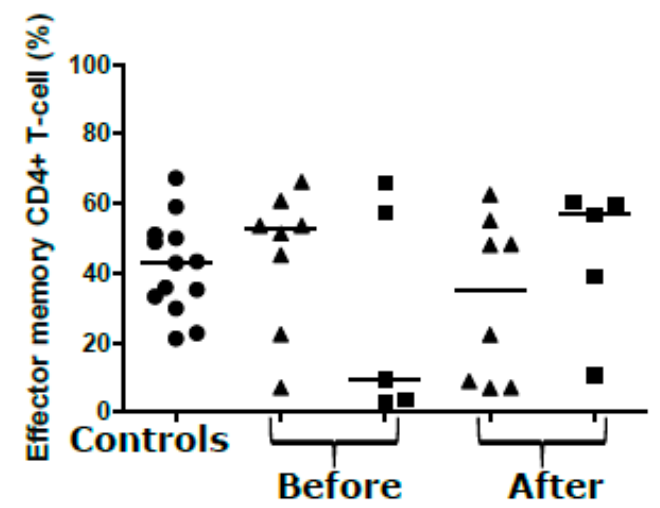

B.

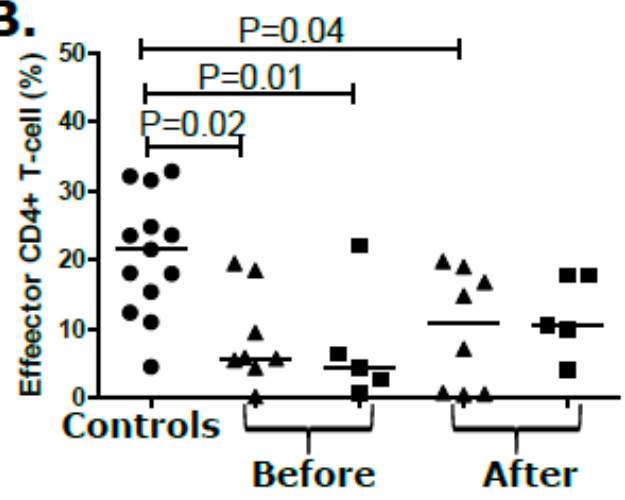

D.

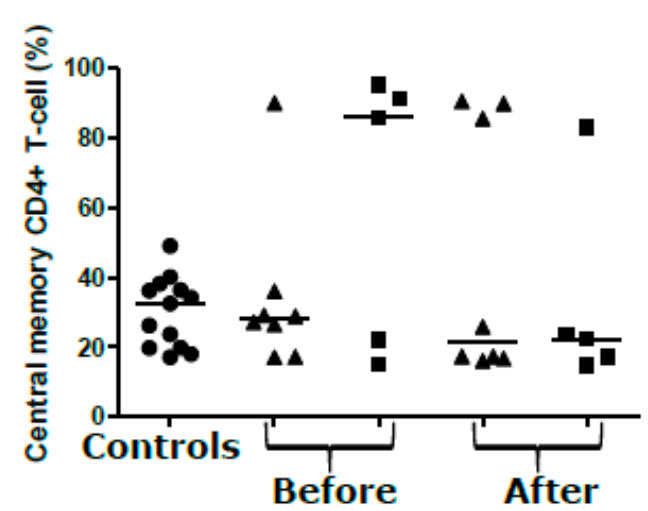

Figure 4. T-cell population $\left(\mathrm{CD}^{+}\right)$analysis from peripheral blood mononuclear cells (PBMCs). Percentage of $\mathrm{CD}^{+}$T-cell population expressing markers of $(\mathbf{A})$ naïve, $(\mathbf{B})$ effector, $(\mathbf{C})$ effector memory, and (D) central memory $\mathrm{CD}^{+}{ }^{+} \mathrm{T}$-cells in asymptomatic controls and responder and non-responders before and after treatment. 

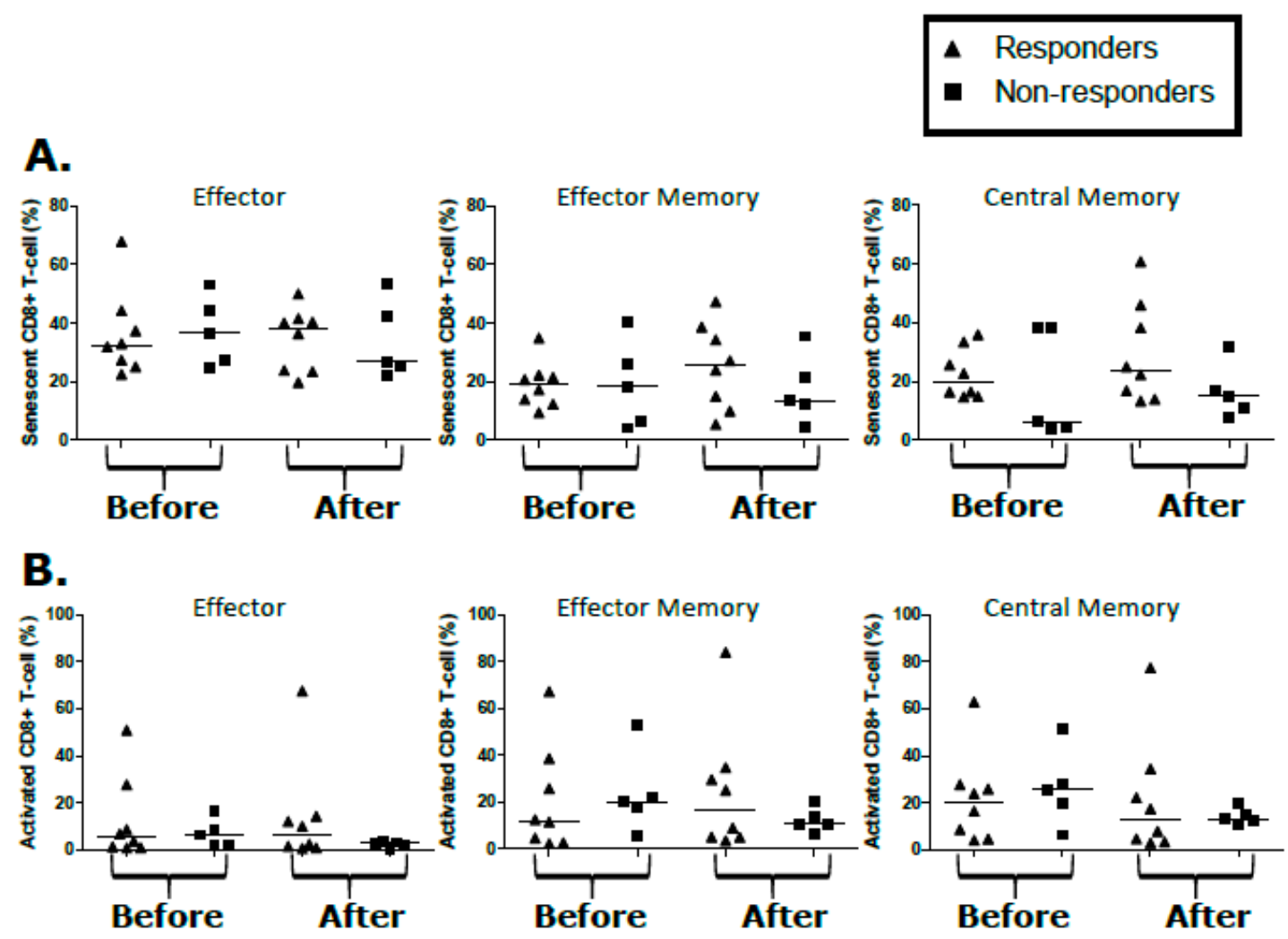

Figure 5. T-cell population $\left(\mathrm{CD}^{+}\right)$analysis from peripheral blood mononuclear cells (PBMCs). (A) Percentage of $\mathrm{CD} 8^{+} \mathrm{T}$-cell expressing senescence markers $\left(\mathrm{CD} 57^{+} / \mathrm{CD} 28^{-} / \mathrm{CD} 27^{-}\right)$among subsets of $\mathrm{CD}^{+}{ }^{+}$T-cells in effector, effector memory, and central memory CD8 ${ }^{+}$T-cells in responders and non-responders before and after KS treatment. (B) Percentage of CD8 ${ }^{+}$T-cell expressing activation markers $\left(\mathrm{CD} 38^{+}\right.$and HLA-DR $\left.{ }^{+}\right)$among subsets of $\mathrm{CD} 8^{+} \mathrm{T}$-cells in effector, effector memory, and central memory $\mathrm{CD}^{+} \mathrm{T}$-cells in responders and non-responders before and after KS treatment.

\section{Discussion}

To our knowledge, this is the first study to investigate viral and immunological parameters as predictors of treatment responses in participants with KS receiving local standard-of-care treatment in SSA. KS presentation is intrinsically variable due to dissimilarities in KS symptomology coupled to variances in HIV-1 immune and virological parameters. We sought to investigate outcome associations in a typically variable KS cohort to identify potential parameters associated with treatment response. We have quantified KSHV and HIV-1 viremia, KSHV-humoral responses, cytokine expression, and T-cell immunophenotypes before and after treatment to identify factors that correlate with the KS clinical response, or lack thereof. An advanced cancer stage is known to correlate with poor treatment outcome [19-22]. In contrast, early diagnosis and treatment associates with improved clinical response and reduced morbidity [16-18]. Our analysis of factors associated with treatment response also revealed a trend toward a favorable treatment outcome for individuals presenting with patch and plaque KS lesions at baseline, and the nodular lesion morphotypes were associated with KS non-responders [33]. This highlights the importance of early identification, diagnosis, and treatment of KS to achieve better treatment outcomes in SSA.

Although KSHV viremia has been investigated as a tumor biomarker [34,35], a study of 684 HIV-1+ individuals with KS and Multicentric Castleman's Disease (MCD) showed plasma KSHV viral load did not predict survival in T0 or T1-staged participants with KS [36,37]. Consistent with these findings, KSHV viremia before or after treatment did not correlate with the KS treatment response in our study. KSHV viremia also did not associate with HIV-1 co-infection [25]. However, plasma 
KSHV viremia decreased as a consequence of chemotherapy/radiotherapy, which is consistent with the report by Lin et al. [36]. Additionally, CD4 ${ }^{+}$T-cell count and HIV-1 viremia did not predict the KS treatment response. Similarly, a Zambian study on participants with early KS, to evaluate the longitudinal response to KS treatment with ART alone, found that HIV-1 viremia and CD4 count before and after treatment also did not differentiate KS responders from non-responders (Ngalamika et al., in submission). The lack of outcome association with both CD4 ${ }^{+}$T-cell count and HIV-1 viremia is also supported by recent reports of incident KS in individuals with high $\mathrm{CD} 4^{+} \mathrm{T}$-cell counts and suppressed HIV-1 viral load [9-13]. Since our transcriptomic analysis of EpKS lesions revealed no evidence for HIV-1 transcripts directly in KS lesions (Lidenge et al. in submission), the lack of outcome association with both the CD4 ${ }^{+}$T-cell count and HIV-1 viremia could be due to an indirect impact of HIV on immune function as opposed to simply $\mathrm{CD} 4^{+} \mathrm{T}$-cell depletion.

Changes in immune parameters such as $\mathrm{CD}^{+}{ }^{+}, \mathrm{CD}^{+}$T-cells, $\mathrm{NK}$, and myeloid derived suppressor cell populations have been suggested to be biomarkers for lung cancer and non-Hodgkin's lymphoma treatment responses $[38,39]$. CD4 ${ }^{+}$T-cell help and cytotoxic activity of $\mathrm{CD}^{+}$and $\mathrm{CD}^{+} \mathrm{T}$-cells play an important role in eliminating infected cells and cancer cells [40]. Poor KS treatment outcomes could result from reductions in $\mathrm{CD}^{+} \mathrm{T}_{\mathrm{E}}$ and $\mathrm{CD} 8^{+} \mathrm{T}_{\mathrm{EM}}$ cells in participants with $\mathrm{KS}$. However, reduction in $\mathrm{CD}^{+} \mathrm{T}_{\mathrm{E}}$ and $\mathrm{CD}^{+} \mathrm{T}_{\mathrm{EM}}$ was also evident in responders suggesting possible T-cell qualitative differentials between responders and non-responders. Unfortunately, whether decreases in $\mathrm{CD}^{+}$ $\mathrm{T}_{\mathrm{E}}$ and $\mathrm{CD}^{+} \mathrm{T}_{\mathrm{EM}}$, or the noted increase in $\mathrm{CD}^{+}$naïve T-cells corresponded to decreased KSHV Ag-specific effector functions could not be determined. Assessment of differentials in functionality of T-cells between treatment responders and non-responders will be important in identifying predictors of the KS treatment response.

Cytokine dysregulation has often been associated with KS development [41,42]. However, longitudinal studies of cytokine responses in African participants with KS are lacking. Only a few studies investigated the role of cytokines in predicting the KS treatment response in US-based patients $[43,44]$. In one study, seven patients on ART were treated with rapamycin. Analysis of viral and immunological parameters revealed no significant changes in plasma KSHV and HIV-1 viral load, CD4 count, IL-6, and VEGF levels between KS responders and non-responders [43]. Similarly, a phase II trial of imatinib in participants with EpKS did not find significant association between the cytokines (IL-6, Rantes, IFN- $\gamma$, and basic fibroblast growth factor) analyzed and the KS treatment response [44]. Despite differences in KS treatment regimens between US and SSA, we consistently found that the IL-6, plasma KSHV, HIV-1 viral load, and CD4 count are not associated with the KS treatment response. Importantly, our study has not found significant association of outcome with any variance in IL-10, IL-5, and CxCL10 that were not previously investigated. However, granulocyte colony stimulating factor (G-CSF) and hepatocyte growth factor (HGF) were reported to correlate with the KS treatment response by Tedeschi et al. in a cohort of Italian participants with advanced EpKS [37]. Unfortunately, incompatibility in assay platforms (Millipore versus BD-CBA) and limited blood samples from participants with advanced KS prevented us from investigating G-CSF and HGF in this study. Overall, the Th2 skewing of cytokines we previously reported in pre-treated African participants with KS did not change significantly despite the demonstrated clinical KS response, and will not be good markers for the treatment response [25].

In acute viral infections, $\mathrm{nAb}$ responses often correlate with protection or control. However, for Epstein-Barr virus (EBV) and KSHV, high antibody titers are often associated with disease $[45,46]$. Our analysis of pre-treatment $\mathrm{KSHV}-\mathrm{nAb}$ revealed higher prevalence and titers of $\mathrm{nAb}$ in both participants with EpKS and EnKS than in asymptomatic controls [25,30]. In this case, despite decreased KSHV viremia, total anti-KSHV and KSHV-nAb in participants with KS remained persistently high in both responders and non-responders. This is similar to the results observed from the analysis of participants with early KS treated with ART only (Ngalamika et al. in submission). It is possible that the high KSHV-humoral responses result from continued production of antibody-associated cytokines IL-6, 
IL-5, and IL-10 evident in both studies, even though the Ab response does not appear to contribute to KS control.

It is puzzling that none of the immune parameters assessed predicted KS treatment response despite the strong association between KS and immune suppression. Furthermore, it was noted that a reduction in size and number of KS lesions after treatment did not correlate with the magnitude of the immunological responses measured to date. This implies that the response requires modulation of the qualitative or functional aspects of immune control. The lack of significant changes potentially explains the short-lived clinical responses and high recurrence rates reported in other studies $[13,21]$. As suggested by Roshan et al., weak, and individualized T-cell functional responses (IFN- $\gamma$ ) against KSHV, coupled with a lack of immunodominant epitopes, seem to be common features in participants with KS and in asymptomatic controls [47]. It is possible that differences between treatment responders and non-responders lie in the differences in the T-cell functional repertoire against KSHV and KS. Other host factors such as the HLA type or efficiency of viral/tumor Ag presentation may also play a role in determining the response to treatment in participants with KS. Further functional studies over the course of treatment will be essential to define relationships between host factors and functional T-cell responses that determine the KS treatment outcome. The extent of KS disease prior to initiation of treatment appears to be more important than viral and immunological parameters assessed later in the disease.

A limitation of our study is the small sample size. The stringent recruitment criteria to ensure that only confirmed KS cases are analyzed has limited our sample size and, hence, the depth of our analyses. Thus, it is unlikely that subtle immunological differences between the treatment responders and non-responders can be detected. Additionally, late disease presentation due to the lack of mechanisms for identification of early KS, together with losses during follow-up, have limited our sample size and the depth of our investigations. Larger studies with close patient follow-up are warranted to fully characterize viral and immunological factors associated with the KS treatment response. However, this study highlights the fact that immune dysregulation in participants with KS persists despite a reduction in size and number of lesions in some participants. Additionally, the tested viral and immunological parameters did not predict the KS treatment response in SSA.

\section{Materials and Methods}

\subsection{Study Design, Subjects, and Samples}

The cohort was comprised of 26 study subjects who were $\geq 18$ years of age and of both genders from Ocean Road Cancer Institute (ORCI), Dar es Salaam including 13 participants with KS and $13 \mathrm{KSHV}$-infected asymptomatic controls. Seven of the controls were HIV-1 ${ }^{+}$and six were HIV-1-. Consenting subjects with complete clinical and treatment information were recruited. Only participants with KS who were newly diagnosed, histologically confirmed, and KS biopsy KSHV-DNA PCR positive at baseline were included. This is to avoid the approximately $35 \%$ misdiagnosed cases resulting from only clinical and/or histopathology diagnosed cases in SSA [48,49]. Peripheral blood samples were collected at baseline and at 3-12 months post-therapy cessation. Plasma was HIV-1 tested and the KSHV viral load was quantified by real-time PCR. KS tumor biopsy samples $(4 \mathrm{~mm})$ were collected (baseline only). All study procedures were approved by the institutional review boards from the Tanzania National Institute for Medical Research, Ocean Road Cancer Institute, and the University of Nebraska-Lincoln (UNL), IRB number: 20141014709FB.

\subsection{Kaposi's Sarcoma Response Criteria}

According to ORCI treatment guidelines, all participants with EpKS, who were not on ART, began ART immediately after diagnosis. Depending on the extent of KS disease, patients are then treated with combined chemotherapy consisting of six cycles of adriamycin, bleomycin, and vinblastine/vincristine (ABV) or radiotherapy (XRT). In this study, the KS treatment response was determined 3 months after 
completion of ABV chemotherapy or XRT. Some KS treatment responders maintained their remission status up to 12 months after completion of treatment. A responder was defined under the AIDS Clinical Trial Group (ACTG) clinical response criteria for a complete and partial response while non-responders included stable and progressive disease [50]. For statistical analysis, all patients were defined as either responders or non-responders. In cases where patch, plaque, and nodular KS lesions existed in the same patient, the most advanced KS lesion was used to define the lesion morphotype.

\subsection{HIV-1 Status and HIV-1 and KSHV Quantification in Plasma and Tumor Tissues}

HIV-1 infection status and quantification of plasma HIV-1 viral load before and after treatment were performed as previously described [25]. Extraction of KSHV viral DNA from plasma, and KS tumor biopsies followed by real-time PCR amplification of KSHV-ORF26 were conducted as previously described [25].

\section{4. rKSHV.219 Production, KSHV Serology, and Neutralization Assays}

The rKSHV.219 was generated and tittered on HEK293T cells as previously described [25,51]. Levels and titers of the KSHV antibody $(\mathrm{Ab})$ and neutralizing antibody $(\mathrm{nAb})$ were determined as previously described [25]. Heat inactivated plasma was incubated at 1:50 dilution with rKSHV.219 at $37{ }^{\circ} \mathrm{C}$ for one hour. A virus-plasma mixture was used to infect HEK293T cells at $37{ }^{\circ} \mathrm{C}$ for $72 \mathrm{~h}$. Flow cytometry was used to quantify infection. Plasma samples demonstrating $>50 \%$ inhibition of infection compared to a negative control plasma were categorized as neutralizing. All samples that were KSHV-nAb positive at the 1:50 dilution were re-assayed in two-fold dilutions of plasma from 1:50 to $1: 800$ to define the $50 \%$ inhibitory concentration $\left(\mathrm{IC}_{50}\right)$.

\subsection{Multiplex Bead-Based Immunoassay}

Plasma cytokines and chemokines were quantified with Becton-Dickinson Cytometric-Bead-Array (CBA) FlexSet kits, according to the manufacturer's protocol. The standard sensitivity array (picograms/mL) included interleukin-4 (IL-4), chemokine CxCL10, interleukin-5 (IL-5), and transforming growth factor- $\beta$ (TGF- $\beta$ ). The enhanced sensitivity array (femtograms/mL) included interferon- $\gamma($ IFN- $\gamma)$, interleukin-1 $\beta$ (IL-1 $\beta)$, interleukin-6 (IL-6), interleukin-12p70 (IL-12p70), interleukin-17A (IL-17A), interleukin-10 (IL-10), and tumor necrosis factor- $\alpha$ (TNF- $\alpha$ ). Raw data were collected on an Accuri C6 Plus cytometer (BD-Biosciences, San Jose, CA, USA) and analyzed with FlowJo version-10 (TreeStar, Ashland, OR, USA).

\subsection{Flow Cytometry}

To immunophenotype cell populations, PBMC were thawed, washed, split into two panels, and stained for $10 \mathrm{~min}$ in the dark at room temperature with antibodies against the following human surface markers: CD3 Percp.Cy5.5 (BD-Biosciences, San Jose, CA, USA), CD4, CD8-FITC, CD45RO-APC, CD197-AlexaFluor-700, CD38-BV510, HLA-DR-PE.Cy7, CD28-BV711, CD27 PE-Dazzle-594, CD57-APC, and CD107a BV421(Biolegend, San Diego, CA, USA). The cells were fixed using Perm/fix (BD-Biosciences, San Jose, CA, USA) for $20 \mathrm{~min}$ at $4{ }^{\circ} \mathrm{C}$ in the dark, and then stained for intracellular Ki67 (Biolegend, San Diego, CA, USA) or IFN- $\gamma$ (Biolegend, San Diego, CA, USA). Raw data were quantified by FACSAria (BD-Biosciences, San Jose, CA, USA) and analyzed with FlowJo version-10.

\subsection{Statistical Analysis}

Viral nucleic acid detection in plasma, antibody, and cytokine responses as well as T-cell immunophenotypes were stratified into high and low levels before and after KS treatment. Correlation with the treatment response was analyzed. One-way analysis of variance with Tukey's multiple comparison test and non-parametric Mann-Whitney t-test were employed to determine differences between groups. One control group was $\left(\mathrm{KSHV}^{+} / \mathrm{HIV}-1^{+}\right)$similar to EpKS patients in order to control 
for viral co-infection and investigate the effect of cancer (KS) in the background of HIV-1 co-infection on T-cell phenotypes while the other group of controls was $\left(\mathrm{KSHV}^{+}, \mathrm{HIV}-1^{-}\right)$similar to EnKS patients in order to control for KSHV infection and investigate the effect of cancer (KS) in the absence of HIV-1 co-infection on T-cell phenotypes. Similar analyses on cytokine and antibody responses have been reported previously [25]. The effect of the variables as predictors of KS treatment response was determined by logistic regression using SAS version 9.4 software (SAS Institute, Cary, NC, USA). GraphPad Prism v5 (GraphPad Software, San Diego, CA, USA) was used for statistical analyses. All tests were 2 -tailed, and $p$-values $<0.05$ were considered significant.

\section{Conclusions}

In summary, there was a trend toward favorable treatment outcomes in patch and plaque stages of KS. Our study tested KSHV and HIV-1 viremia, CD4 T-cell counts, KSHV-humoral responses, various cytokine responses, and the magnitude of T-cell population subsets as predictors of the KS treatment response but did not find significant associations. An important finding of this study is that, despite favorable clinical responses in some participants with KS, immunological dysregulation observed at baseline, persisted in these patients in remission, and this likely contributes to the high KS recurrence rates.

Supplementary Materials: The following are available online at http://www.mdpi.com/2072-6694/12/6/1594/s1. Figure S1: T-cell population analysis from peripheral blood mononuclear cells (PBMCs). Figure S2: T-cell population analysis from peripheral blood mononuclear cells (PBMCs).

Author Contributions: Conceptualization, S.J.L., F.Y.T., J.T.W., and C.W. Methodology, S.J.L., F.Y.T., J.T.W., and C.W. Formal Analysis, S.J.L., F.Y.T., D.M.S., J.T.W., and C.W. Investigation, S.J.L., F.Y.T., Y.M., and D.M.S. Resources, J.R.N., J.M., J.T.W., and C.W. Data Curation, S.J.L., J.R.N., J.M., J.T.W., and C.W. Writing-Original Draft Preparation, S.J.L. Writing-Review \& Editing, S.J.L., F.Y.T., J.T.W., and C.W. Visualization, S.J.L. Supervision, J.M., J.T.W., and C.W. Project Administration, J.M., J.T.W., and C.W. Funding Acquisition, J.M., J.T.W., and C.W. All authors interpreted the results, reviewed the drafts, and approved the final version.

Funding: This work was supported by the US National Institute of Health, National Cancer Institute grants (U54 CA190155) to CW/JTW, Fogarty International Center grant (K43TW011418) to SJL, and National Institute of General Medical Science grant (P30 GM103509) to CW.

Acknowledgments: We thank all study participants for their participation in this study as well as all staff at the Ocean Cancer Institute for recruiting participants, sample processing, and data management.

Conflicts of Interest: All authors declare no conflict of interest.

\section{References}

1. David, M.; Peter, M.; Damania, B.A.; Cesarman, E. Chapter 65 Kaposi's Sarcoma-Associated Herpesvirus. In Fields Virology; American Society of Microbiology: Washington, DC, USA, 2013; Volume 6, pp. 1-72.

2. Dollard, S.C.; Butler, L.M.; Jones, A.M.G.; Mermin, J.H.; Chidzonga, M.; Chipato, T.; Shiboski, C.H.; Brander, C.; Mosam, A.; Kiepiela, P.; et al. Substantial regional differences in human herpesvirus 8 seroprevalence in sub-Saharan Africa: Insights on the origin of the "Kaposi's sarcoma belt". Int. J. Cancer 2010, 127, 2395-2401. [CrossRef] [PubMed]

3. Nalwoga, A.; Cose, S.; Wakeham, K.; Miley, W.; Ndibazza, J.; Drakeley, C.; Elliott, A.; Whitby, D.; Newton, R. Association between malaria exposure and Kaposi's sarcoma-associated herpes virus seropositivity in Uganda. Trop. Med. Int. Health 2015, 20, 665-672. Available online: https://www.ncbi.nlm.nih.gov/pmc/ articles/PMC4390463/pdf/tmi0020-0665.pdf (accessed on 7 August 2018). [CrossRef] [PubMed]

4. Newton, R.; Labo, N.; Wakeham, K.; Miley, W.; Asiki, G.; Johnston, W.T.; Whitby, D. Kaposi sarcoma-associated herpesvirus in a rural Ugandan cohort, 1992-2008. J. Infect. Dis. 2018, 217, 263-269. Available online: https://academic.oup.com/jid/article/217/2/263/4584515 (accessed on 7 August 2018). [CrossRef] [PubMed]

5. Cook-Mozaffari, P.; Newton, R.; Beral, V.; Burkitt, D.P. The geographical distribution of Kaposi's sarcoma and of lymphomas in Africa before the AIDS epidemic. Br. J. Cancer 1998, 78, 1521-1528. Available online: http://www.pubmedcentral.nih.gov/articlerender.fcgi?artid=2063225\&tool=pmcentrez\&rendertype= abstract (accessed on 7 August 2018). [CrossRef] 
6. McHardy, J.; Williams, E.H.; Geser, A.; De-Thé, G.; Beth, E.; Giraldo, G. Endemic Kaposi's sarcoma: Incidence and risk factors in the west Nile district Of Uganda. Int. J. Cancer 1984, 33, 203-212. [CrossRef]

7. Wabinga, H.R.; Parkin, D.M.; Wabwire-Mangen, F.; Nambooze, S. Trends in cancer incidence in Kyadondo County, Uganda, 1960-1997. Br. J. Cancer 2000, 82, 1585-1592. Available online: http://www.ncbi.nlm.nih. gov/pubmed/10789729 (accessed on 17 May 2017).

8. Chokunonga, E.; Levy, L.M.; Bassett, M.T.; Mauchaza, B.G.; Thomas, D.B.; Parkin, D.M. Cancer incidence in the African population of Harare, Zimbabwe: Second results from the cancer registry 1993-1995. Int. J. Cancer 2000, 85, 54-59. Available online: http://www.embase.com/search/results? subaction=viewrecord\& from=export\&id=L29573301 (accessed on 3 December 2019). [CrossRef]

9. Semeere, A.S.; Busakhala, N.; Martin, J.N. Impact of antiretroviral therapy on the incidence of Kaposi's sarcoma in resource-rich and resource-limited settings. Curr. Opin. Oncol. 2012, 24, 522-530. Available online: http://www.ncbi.nlm.nih.gov/pubmed/22729153 (accessed on 26 September 2018). [CrossRef]

10. Chan, J.; Kravcik, S.; Angel, J.B. Development of Kaposi's sarcoma despite sustained suppression of HIV plasma viremia. J. Acquir. Immune Defic. Syndr. 2000, 23, 361.

11. Maurer, T.; Ponte, M.; Leslie, K. HIV-associated Kaposi's sarcoma with a high CD4 count and a low viral load. N. Engl. J. Med. 2007, 357, 1352-1353. [CrossRef]

12. Crum-Cianflone, N.F.; Hullsiek, K.H.; Ganesan, A. Is Kaposi's sarcoma occurring at higher CD4 cell counts over the course of the HIV epidemic? AIDS 2010, 24, 2881-2883. Available online: http://www.ncbi.nlm.nih. gov/pubmed/20827160 (accessed on 26 September 2018). [CrossRef] [PubMed]

13. Palich, R.; Veyri, M.; Valantin, M.-A.; Marcelin, A.-G.; Guihot, A.; Pourcher, V.; Jary, A.; Solas, C.; Makinson, A.; Poizot-Martin, I.; et al. Recurrence and occurrence of Kaposi's sarcoma in HIV-infected patients on antiretroviral therapy despite suppressed HIV viremia. Clin Infect Dis 2020, 70, 2435-2438. [CrossRef] [PubMed]

14. El-Mallawany, N.K.; McAtee, C.; Campbell, L.R.; Kazembe, P.N. Pediatric Kaposi sarcoma in context of the HIV epidemic in sub-Saharan Africa: Current perspectives. Pediatr. Health Med. Ther. 2018, 9, 35-46. [CrossRef]

15. Irira, M.; Ngocho, J.S.; Youze, J. Prevalence and outcome of HIV-associated malignancies among HIV-infected children enrolled into care at Kilimanjaro Christian medical center 2006 to 2014: A hospital-based retrospective analytical study. J. Pediatr. Hematol. Oncol. 2018. [CrossRef]

16. Makombe, S.D.; Harries, A.D.; Yu, J.K.L.; Mindy Hochgesang, M.; Mhango, E.; Weigel, R.; Pasulani, O.; Fitzgerald, M.; Schouten, E.J.; Libamba, E.; et al. Outcomes of patients with Kaposi's sarcomawho start antiretroviral therapy under routine programme conditions in Malawi. Trop Doct. 2008, 38, 5-7. [CrossRef]

17. Chalya, P.L.; Mbunda, F.; Rambau, P.; Jaka, H.; Masalu, N.; Mirambo, M.M.; Mushi, M.F.; Kalluvya, S. Kaposi's sarcoma: A 10-year experience with 248 patients at a single tertiary care hospital in Tanzania. BMC Res. Notes 2015, 8, 440. [CrossRef] [PubMed]

18. World Health Organization. Estimated Cancer Incidence, Mortality and Prevalence in Tanzania 2012. Available online: http://globocan.iarc.fr/Pages/fact_sheets_population.aspx (accessed on 1 June 2017).

19. Mwafongo, A.A.; Rosenberg, N.E.; Ng'Ambi, W.; Werner, A.B.; Garneau, W.M.; Gumulira, J.; Phiri, S.; Hosseinipour, M.C. Treatment outcomes of AIDS-associated Kaposi's sarcoma under a routine antiretroviral therapy program in Lilongwe, Malawi: Bleomycin/vincristine compared to vincristine monotherapy. PLoS ONE 2014, 9, e91020. [CrossRef] [PubMed]

20. Fardhdiani, V.; Molfino, L.; Zamudio, A.G.; Manuel, R.; Luciano, G.; Ciglenecki, I.; Rusch, B.; Toutous-Trellu, L.; Coldiron, M.E. HIV-associated Kaposi's sarcoma in Maputo, Mozambique: Outcomes in a specialized treatment center, 2010-2015. Infect. Agents Cancer 2018, 13, 5. [CrossRef]

21. Mtonga, W.; Mujajati, A.; Munkombwe, D.; Kalungia, A.C.; Muungo, L.T.; West, J.; Wood, C.; Ngalamika, O. Therapeutic outcomes in AIDS-associated Kaposi's sarcoma patients on antiretroviral therapy treated with chemotherapy at two tertiary hospitals in Lusaka, Zambia. Curr. HIV Res. 2018, 16, 231-236. Available online: http://www.ncbi.nlm.nih.gov/pubmed/29992888 (accessed on 31 December 2019). [CrossRef]

22. Ramaswami, R.; Uldrick, T.S.; Polizzotto, M.N.; Wyvill, K.M.; Goncalves, P.; Widell, A.; Lurain, K.; Steinberg, S.M.; Figg, W.D.; Tosato, G.; et al. A pilot study of liposomal doxorubicin combined with bevacizumab followed by bevacizumab monotherapy in patients with advanced Kaposi sarcoma. Clin. Cancer Res. 2019, 25, 4238-4247. [CrossRef] 
23. Gantt, S.; Kakuru, A.; Wald, A.; Walusansa, V.; Corey, L.; Casper, C.; Orem, J. Clinical presentation and outcome of epidemic Kaposi sarcoma in Ugandan children. Pediatr. Blood Cancer 2010, 54, 670-674. [CrossRef] [PubMed]

24. Martín-Carbonero, L.; Barrios, A.; Saballs, P.; Sirera, G.; Santos, J.; Palacios, R.; Valencia, M.E.; Alegre, M.; Podzamczer, D.; Gonzalez-Lahoz, J.; et al. Pegylated liposomal doxorubicin plus highly active antiretroviral therapy versus highly active antiretroviral therapy alone in HIV patients with Kaposi's sarcoma. AIDS 2004, 18, 1737-1740. [CrossRef] [PubMed]

25. Lidenge, S.J.; Tso, F.Y.; Ngalamika, O.; Ngowi, J.R.; Mortazavi, Y.; Kwon, E.H.; Shea, D.M.; Minhas, V.; Mwaiselage, J.; Wood, C.; et al. Similar immunological profiles between african endemic and human immunodeficiency virus type 1-associated epidemic Kaposi Sarcoma (KS) patients reveal the primary role of KS-Associated Herpesvirus in KS pathogenesis. J. Infect. Dis. 2018, 219, 1318-1328. Available online: https:/academic.oup.com/jid/article-abstract/219/8/1318/5191126 (accessed on 11 May 2020). [CrossRef] [PubMed]

26. Xu, Q.; Katakura, Y.; Yamashita, M.; Fang, S.; Tamura, T.; Matsumoto, S.-E.; Aiba, Y.; Teruya, K.; Osada, K.; Nishikawa, R.; et al. IL-10 augments antibody production in in vitro immunized lymphocytes by inducing a Th2-type response and B cell maturation. Biosci. Biotechnol. Biochem. 2004, 68, 2279-2284. Available online: http://www.ncbi.nlm.nih.gov/pubmed/15564665 (accessed on 15 March 2020). [CrossRef]

27. Kouro, T.; Takatsu, K. IL-5- and eosinophil-mediated inflammation: From discovery to therapy. Int. Immunol. 2009, 21, 1303-1309. Available online: https://academic.oup.com/intimm/article-abstract/21/12/1303/686327 (accessed on 14 August 2018). [CrossRef]

28. Dienz, O.; Eaton, S.M.; Bond, J.P.; Neveu, W.; Moquin, D.; Noubade, R.; Briso, E.M.; Charland, C.; Leonard, W.J.; Ciliberto, G.; et al. The induction of antibody production by IL-6 is indirectly mediated by IL-21 produced by CD4+ T cells. J. Exp. Med. 2009, 206, 69-78. [CrossRef]

29. Saxena, A.; Khosraviani, S.; Noel, S.; Mohan, D.; Donner, T.; Hamad, A.R. Interleukin-10 paradox: A potent immunoregulatory cytokine that has been difficult to harness for immunotherapy. Cytokine 2014, 74, $27-34$. [CrossRef]

30. Kumar, P.; Kuwa, N.Y.; Minhas, V.; Marimo, C.; Shea, D.M.; Kankasa, C.; Wood, C. Higher levels of neutralizing antibodies against KSHV in KS patients compared to asymptomatic individuals from Zambia. PLoS ONE 2013, 8, e71254. Available online: http://www.pubmedcentral.nih.gov/articlerender.fcgi?artid= 3743886\&tool=pmcentrez\&rendertype $=$ abstract (accessed on 2 December 2015). [CrossRef]

31. Weninger, W.; Manjunath, N.; Von Andrian, U.H. Migration and differentiation of CD8+ T cells. Immunol. Rev. 2002, 186, 221-233. [CrossRef]

32. Marelli-Berg, F.; Cannella, L.; Dazzi, F.; Mirenda, V. The highway code of T cell trafficking. J. Pathol. 2008, 214, 179-189. [CrossRef]

33. Radu, O.; Pantanowitz, L. Kaposi Sarcoma. Arch. Pathol. Lab. Med. 2013, 137, 289-294. [CrossRef] [PubMed]

34. Borok, M.Z.; Fiorillo, S.; Gudza, I.; Putnam, B.; Ndemera, B.; White, I.E.; Gwanzura, L.; Schooley, R.T.; Campbell, T.B. Evaluation of plasma human herpesvirus 8 DNA as a marker of clinical outcomes during antiretroviral therapy for AIDS-related Kaposi sarcoma in Zimbabwe. Clin. Infect. Dis. 2010, 51, 342-349. [CrossRef] [PubMed]

35. Haq, I.-U.; Pria, A.D.; Papanastasopoulos, P.; Stegmann, K.; Bradshaw, D.; Nelson, M.; Bower, M. The clinical application of plasma Kaposi sarcoma herpesvirus viral load as a tumour biomarker: Results from 704 patients. HIV Med. 2015, 17, 56-61. [CrossRef] [PubMed]

36. Lin, L.; Lee, J.Y.; Kaplan, L.D.; Dezube, B.J.; Noy, A.; Krown, S.E.; Levine, A.M.; Yu, Y.; Hayward, G.S.; Ambinder, R.F.; et al. Effects of chemotherapy in AIDS-associated non-Hodgkin's lymphoma on Kaposi's sarcoma Herpesvirus DNA in blood. J. Clin. Oncol. 2009, 27, 2496-2502. Available online: http://www.ncbi. nlm.nih.gov/pubmed/19349542 (accessed on 7 January 2020). [CrossRef]

37. Tedeschi, R.; Bidoli, E.; Bortolin, M.T.; Schioppa, O.; Vaccher, E.; De Paoli, P. Plasma biomarkers of clinical response during chemotherapy plus combination antiretroviral therapy (cART) in HIV+ patients with advanced Kaposi sarcoma. Oncotarget 2015, 6, 30334-30342. [CrossRef]

38. Bower, M.; Stebbing, J.; Tuthill, M.; Campbell, V.; Krell, J.; Holmes, P.; Ozzard, A.; Nelson, M.; Gazzard, B.; Powles, T.; et al. Immunologic recovery in survivors following chemotherapy for AIDS-related non-Hodgkin lymphoma. Blood 2008, 111, 3986-3990. [CrossRef] 
39. Bonomi, M.; Ahmed, T.; Addo, S.; Kooshki, M.; Palmieri, D.; Levine, B.J.; Ruiz, J.; Grant, S.; Petty, W.J.; Triozzi, P.L.; et al. Circulating immune biomarkers as predictors of the response to pembrolizumab and weekly low dose carboplatin and paclitaxel in NSCLC and poor PS: An interim analysis. Oncol. Lett. 2018, 17, 1349-1356. [CrossRef]

40. Ostroumov, D.; Fekete-Drimusz, N.; Saborowski, M.; Kühnel, F.; Woller, N. CD4 and CD8 T lymphocyte interplay in controlling tumor growth. Cell. Mol. Life Sci. 2017, 75, 689-713. [CrossRef]

41. Uldrick, T.S.; Wang, V.; O’Mahony, D.; Aleman, K.; Wyvill, K.M.; Marshall, V.; Steinberg, S.M.; Pittaluga, S.; Maric, I.; Whitby, D.; et al. An interleukin-6-related systemic inflammatory syndrome in patients co-infected with Kaposi sarcoma-associated herpesvirus and HIV but without Multicentric Castleman disease. Clin. Infect. Dis. 2010, 51, 350-358. Available online: http://www.pubmedcentral.nih.gov/articlerender.fcgi?artid= 2946207\&tool=pmcentrez\&rendertype $=$ abstract (accessed on 7 January 2020). [CrossRef]

42. Host, K.M.; Jacobs, S.R.; West, J.A.; Zhang, Z.; Costantini, L.M.; Stopford, C.M.; Dittmer, D.P.; Damania, B. Kaposi's Sarcoma-associated Herpesvirus increases PD-L1 and Proinflammatory Cytokine expression in human monocytes. mBio 2017, 8. Available online: https://www.ncbi.nlm.nih.gov/pmc/articles/PMC5635685/ pdf/mBio.00917-17.pdf (accessed on 8 August 2018). [CrossRef]

43. Krown, S.E.; Roy, D.; Lee, J.Y.; Dezube, B.J.; Reid, E.G.; Venkataramanan, R.; Han, K.; Cesarman, E.; Dittmer, D.P. Rapamycin With Antiretroviral Therapy in AIDS-Associated Kaposi Sarcoma: An AIDS malignancy consortium study. JAIDS J. Acquir. Immune Defic. Syndr. 2012, 59, 447-454. [CrossRef] [PubMed]

44. Koon, H.B.; Krown, S.E.; Lee, J.Y.; Honda, K.; Rapisuwon, S.; Wang, Z.; Aboulafia, D.; Reid, E.G.; Rudek, M.A.; Dezube, B.J.; et al. Phase II trial of imatinib in AIDS-associated Kaposi's Sarcoma: AIDS malignancy consortium protocol 042. J. Clin. Oncol. 2014, 32, 402-408. Available online: http://www.ncbi.nlm.nih.gov/ pubmed/24378417 (accessed on 15 March 2020). [CrossRef] [PubMed]

45. Coghill, A.E.; Hildesheim, A. Epstein-barr virus antibodies and the risk of associated malignancies: Review of the literature. Am. J. Epidemiol. 2014, 180, 687-695. Available online: http://www.ncbi.nlm.nih.gov/ pubmed/25167864 (accessed on 19 October 2018). [CrossRef] [PubMed]

46. Wakeham, K.; Johnston, W.T.; Nalwoga, A.; Webb, E.L.; Mayanja, B.N.; Miley, W.; Elliott, A.; Whitby, D.; Newton, R. Trends in Kaposi's sarcoma-associated Herpesvirus antibodies prior to the development of HIV-associated Kaposi's sarcoma: A nested case-control study. Int. J. Cancer 2014, 136, 2822-2830. Available online: http://www.ncbi.nlm.nih.gov/pubmed/25395177 (accessed on 19 October 2018). [CrossRef] [PubMed]

47. Roshan, R.; Labo, N.; Trivett, M.; Miley, W.; Marshall, V.; Coren, L.; Castro, E.M.C.; Perez, H.; Holdridge, B.; Davis, E.; et al. T-cell responses to KSHV infection: A systematic approach. Oncotarget 2017, 8, 109402-109416. Available online: http://www.ncbi.nlm.nih.gov/pubmed/29312617 (accessed on 8 January 2020). [CrossRef] [PubMed]

48. Van Bogaert, L.-J. Clinicopathological proficiency in the diagnosis of Kaposi's Sarcoma. ISRN AIDS 2012, 2012, 1-7. Available online: http://www.ncbi.nlm.nih.gov/pubmed/24052878 (accessed on 17 October 2018). [CrossRef]

49. Amerson, E.H.; Woodruff, C.M.; Forrestel, A.; Wenger, M.; McCalmont, T.; LeBoit, P.; Maurer, T.; Laker-Oketta, M.; Muyindike, W.; Bwana, M.; et al. Accuracy of clinical suspicion and pathologic diagnosis of kaposi sarcoma in East Africa. JAIDS J. Acquir. Immune Defic. Syndr. 2016, 71, 295-301. Available online: http://www.ncbi.nlm.nih.gov/pubmed/26452066 (accessed on 17 October 2018). [CrossRef]

50. Krown, S.E.; Testa, M.A.; Huang, J. Aids-related Kaposi's sarcoma: Prospective validation of the AIDS clinical trials group staging classification. J. Clin. Oncol. Am. Soc. Clin. Oncol. 1997, 15, 3085-3092. [CrossRef]

51. Vieira, J.; O'Hearn, P.M. Use of the red fluorescent protein as a marker of Kaposi's sarcoma-associated herpesvirus lytic gene expression. Virology 2004, 325, 225-240. Available online: http://ac.els-cdn.com/S0042682204002284/1-s2.0-S0042682204002284-main.pdf?_tid=f331a708-47dc11e7-852d-00000aab0f6c\&acdnat=1496440175_4714b3413ecfb09f17ec515735c3da12 (accessed on 2 June 2017). [CrossRef]

(C) 2020 by the authors. Licensee MDPI, Basel, Switzerland. This article is an open access article distributed under the terms and conditions of the Creative Commons Attribution (CC BY) license (http://creativecommons.org/licenses/by/4.0/). 